\title{
SPANISH BROOM (SPARTIUM JUNCEUM L.) - FEEDSTOCK FOR BIOPLASTIC AND BIOENERGY INDUSTRY
}

\author{
Zorana Kovačević*, Vanja Jurišić ${ }^{* *}$, Mateja Grubor ${ }^{* *}$, Ana Matin ${ }^{* *}$, \\ Tajana Krička ${ }^{* *}$, Sandra Bischof \\ ${ }^{*}$ University of Zagreb, Faculty of Textile Technology, Zagreb, Croatia \\ ${ }^{* *}$ University of Zagreb, Faculty of Agriculture, Zagreb, Croatia
}

corresponding author: Zorana Kovačević, e-mail: zorana.kovacevic@ttf.hr

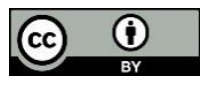

This work is licensed under a

Creative Commons Attribution 4.0

International License
Original scientific paper

Received: June $26^{\text {th }}$, 2019

Accepted: July 15 ${ }^{\text {th }}, 2019$

HAE- 1915

https://doi.org/10.33765/thate.9.3.1

\begin{abstract}
Spanish Broom (Spartium junceum L.) is a Mediterranean plant of various usage possibilities. Its fibres were known since ancient time but in some point of last century, more accurately in 1950s, their production was abandoned due to the negative economic effect. Another drawback was large time consumption, especially during the old tradition method - Spanish Broom maceration in salt water. Nowadays, due to technology development and ecological awareness, it is much easier to produce Spanish Broom fibres of enhanced quality. One of the fibre extraction methods is the one assisted with microwave oven. Demerit of such fibre production is in large residue content after obtaining fibres - approx. $90 \%$ of initial Spanish Broom weight.

Due to the need for finding sustainable solutions in the development of new materials, the usage of Spanish Broom fibres in the service of reinforcement for biopolymer poly (lactic acid) (PLA) matrix was investigated. Obtained results target our further research into the direction of Spanish Broom fibres and PLA application in the production of green composites. The aim of this research was to prove that developed product can be categorized under the biodegradable group by investigating its degradation properties using serine endopeptidase enzyme. The results show positive degradation effect while using $50 \mathrm{wt} \%$ (on weight of material) enzyme concentration during a 5-day treatment.

Stem residues of Spanish Broom plant derived from salty water and microwave maceration were further investigated for their potential as raw material for second-generation biofuel production. Examination of its energy properties consisted of determination of proximate and ultimate properties of the biomass. The results show low moisture content $(6.5 \%-7.5 \%)$, ash content below $5 \%$ and higher values of fixed carbon and volatile matter content of $13.2 \%$ and $75 \%$, respectively. Higher heating values that were determined $(17.2-18.8 \mathrm{MJ} / \mathrm{kg})$ indicate a high quality biomass that can be used most effectively in solid biofuel production.
\end{abstract}

Keywords: Spartium junceum L., Spanish Broom, poly(lactic acid), composites, biodegradation, Savinase enzyme, biomass, solid biofuel 


\section{INTRODUCTION}

Spartium junceum L. (SJL) is a shrub-like Mediterranean plant from the family of legumes, Figure 1. It is the only species in the genus Spartium L. It grows up to $1-1.5 \mathrm{~m}$, whereas only older plants grow into smaller trees between 4 to $5 \mathrm{~m}$ of height and 15 to 20 $\mathrm{cm}$ of thickness. It produces intensively yellow flowers, between May and July, and its shoots mature between August and October [1]. Its flowers, seeds, stem, leaves and even root are used for the production of natural dyestuff or oil, the latest being used both for the nutritional purposes, as well as for the essence of perfumes and scents [1].

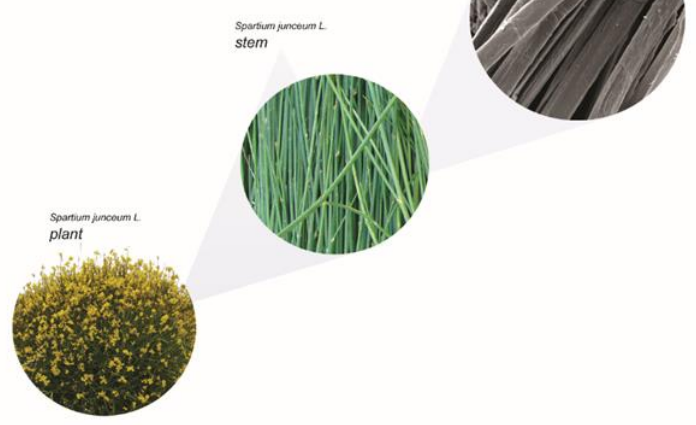

Figure 1. Representation of SJL plant and its structural above ground axis, which is raw material for fibre production; Left to right: SJL shrub during bloom; Freshly harvested SJL stem; Scanning electron micrograph of SJL

fibres extracted from the SJL stem [1]

SJL plant belongs to Fibre crops group based on the Agriculture crop classification, and therefore it has been recognized as excellent raw material for fibre production [2]. Wide distribution of fibre crops is based on the fact that such crops manage to grow in all climate environments (except extremely dry and cold conditions) whose diversity could influence the fibre properties. Therefore, each climate region has one or more fibre crop varieties, which could be utilized delivering economic benefits to rural areas.

SJL fibres belong to the group of bast fibres, sharing similar physico-chemical and mechanical properties with flax fibre which is representative of the bast fibre group [3]. The importance of fibre crops has been known since ancient time in terms of raw materials for garment production or textile products like ropes [1]. Nowadays, the interest is focused on their usage in agriculture, construction, medicine, automotive or chemical industry [4 $6]$.

Kovacevic et al. [7] investigated usage of SJL fibres as reinforcement in polymer matrix for possible application in automotive industry. One of the critical issues of novel research targeting products to be used in automotive industry is application of green and biodegradable materials [8]. Due to the need for finding renewable solutions in the development of new materials, the usage of composite materials made of biopolymer matrices and natural fibres, that are in the service of reinforcement, is increasing significantly. These materials are relatively cheap, they have specific properties, contributing to the neutralization of $\mathrm{CO}_{2}$, and they are biodegradable. Although PLA is biodegradable, the basic understanding of its enzymatic degradation related to its blending with another biodegradable polymer still requires better understanding [9 - 12].

However, both fibre and green composites' production, results in large quantities of residues. In 2013, during Summer school 'From Production to final Use', Cosentino [13] reported on SJL yield as naturally occurring or cultivated crop in the overall areas of $2.5-5.0 \mathrm{t} \mathrm{ha}^{-1}$ and $4.0-7.5 \mathrm{t} \mathrm{ha}^{-1}$, respectively. The fibre yield is usually between $7-12 \%$, depending upon the variety from which it is extracted. These residues, obtained after fibre soaking, are in the liquid form as well as in the crude form, and from the aspect of current global circular economy and bioeconomy strategies, they should be managed somehow.

Hence, the aim of this research was to determine biodegradability of SJL/PLA composite material, and to gain knowledge in the potential of utilizing crude residues after SJL fibre extraction for energy production via direct combustion [14]. 


\section{EXPERIMENTAL}

\section{Materials}

SJL fibres were obtained from the Spanish Broom plant, which was harvested in the area of town Šibenik, Croatia. The plant was collected in the wilderness of nature and harvesting was done by hand using specialized scissors. After fibre extraction through several maceration processes [15 - 17], the plant residue was collected and air-dried for further investigation as biomass for solid biofuel production.

Materials used for biodegradability test were already prepared composite materials made of PLA, SJL fibres and Montmorillonite nanofiller (MMT) which were subjected to enzymatic degradation [17, 18]. The Fluka buffer solutions were used for setting of $\mathrm{pH}$ 9.0 (borax/hydrochloric acid). Enzyme Savinase $16 \mathrm{~L}$ was obtained from Strem Chemicals, Inc. It belongs to class of proteases, more accurately it is serine endopeptidase that catalyses selective hydrolysis of ester bonds. It is in liquid form with optimum conditions being $30-70{ }^{\circ} \mathrm{C}, \mathrm{pH}$ $8-10$ and activity of 16 Kilo Novo Protease Unit KNPU (S/g).

\section{Biodegradability}

The weights of the samples were measured prior to immersing them in separate vials containing approx. $1 \mathrm{~mL}$ of buffer $(\mathrm{pH} 9)$ and Savinase enzyme. The buffer solution was prepared in a $25 \mathrm{~mL}$ flask by adding $2.66 \cdot 10^{-5}$ $\mathrm{mol} / \mathrm{mL} \mathrm{CaCl}_{2}, 5 \mathrm{~mL} 1 \%$ Triton solution and 100, 250 and $500 \mathrm{mg}$ respectively of Savinase enzyme, while pH 9 buffer was added to the $25 \mathrm{~mL}$ mark on the volumetric flask. Since measurements were made on the basis of 5 parallel tests, every single test vial was filled up with $1 \mathrm{~mL}$ of buffer/enzyme solution containing 4, 10 and $20 \mathrm{mg}$ of Savinase and approx. $20 \mathrm{mg}$ of investigated composite material. The enzymatic degradation was performed in the laboratory oven operated at $37^{\circ} \mathrm{C}$ for 5 days.
Prior to immersing into the enzyme solution, the samples were cut into rectangular shape and weighed. The samples were than dried in an oven (Elektrosanitarij, Croatia) at $105 \pm 5$ ${ }^{\circ} \mathrm{C}$ until reaching the constant mass. Every 24 hours, upon immersing into the enzyme solution, samples were thoroughly washed with deionised water and dried again in an oven at $105 \pm 5{ }^{\circ} \mathrm{C}$ for 24 hours. The weights of the samples after enzymatic degradation were measured and the effect of the enzymatic degradation was determined after 24, 72 and 120 hours by weight loss. The percentage of weight loss after enzymatic degradation $\left(\Delta \mathrm{m}_{24,72,120}\right)$ was calculated according the equation (1):

$$
\Delta \mathrm{m}_{24,72,120}=\left(\mathrm{W}_{\mathrm{i}}-\mathrm{W}_{24,72,120}\right) / \mathrm{W}_{\mathrm{i}} \cdot 100
$$

where $\mathrm{W}_{\mathrm{i}}$ is the initial weight measured after oven drying at $105 \pm 5{ }^{\circ} \mathrm{C} ; \mathrm{W}_{24,72,120}$ is the weight after enzymatic degradation within a certain time ( $24 \mathrm{~h}, 72 \mathrm{~h}$ and $120 \mathrm{~h}$ ).

\section{Biofuels properties}

Residue samples after fibre extraction were grounded in a laboratory grinder (IKA Analysentechnik GmbH, Germany). Three replicates of each sample were measured in order to provide reproducibility of the analysis. The biomass samples were analysed according to following standard methods: moisture content (HRN EN 18134-2:2015), ash content (HRN EN ISO 18122:2015), coke content and volatile matter (HRN EN 15148:2009) and fixed carbon (by difference). Carbon, hydrogen, nitrogen and sulphur were determined by the method of dry combustion in a Vario Macro CHNS analyser (Elementar Analysensysteme $\mathrm{GmbH}$, Germany) according to the standard methods HRN EN 15104:2011 and HRN EN 15289:2011, while oxygen content was calculated by difference according to the following formula, where $\mathrm{db}$ stands for dry basis:

$$
\begin{gathered}
\mathrm{O}(\% \mathrm{db})=100-\mathrm{C}(\% \mathrm{db})-\mathrm{H}(\% \mathrm{db})- \\
\mathrm{N}(\% \mathrm{db})-\mathrm{S}(\% \mathrm{db})-\mathrm{ash}(\% \mathrm{db})
\end{gathered}
$$


Heating value was determined according to the HRN EN 14918:2010 standard method by using an oxygen bomb calorimeter (IKA C200 Analysentechnik GmbH, Germany). Heating value is presented as $\mathrm{MJ} / \mathrm{kg}$ on dry basis.

\section{RESULTS AND DISCUSSION}

Description of used samples is presented in Table 1.

Table 1. Description of samples and test conditions in biodegradability examination

\begin{tabular}{|c|c|c|}
\hline Zero sample & Enzyme & Time \\
\hline $\begin{array}{l}\text { PLA - neat } \\
\text { polymer }\end{array}$ & \multirow{5}{*}{$\begin{array}{c}\text { Savinase } 16 \mathrm{~L} \\
\text { - serine } \\
\text { endopeptidase } \\
\text { Concentrations: } \\
20 \%, 50 \% \\
\text { and } 100 \% \text { on } \\
\text { weight of zero } \\
\text { material. } \\
\text { Test } \\
\text { conditions: pH } \\
9, \mathrm{~T}=37^{\circ} \mathrm{C}\end{array}$} & \multirow{5}{*}{$\begin{array}{l}\text { Samples } \\
\text { were } \\
\text { exposed } \\
\text { to } \\
\text { enzymatic } \\
\text { treatment } \\
\text { for } 24,72 \\
\text { and } 120 \\
\text { hours }\end{array}$} \\
\hline $\begin{array}{l}\text { CR - composite } \\
\text { material made of } \\
\text { PLA and SJL } \\
\text { (reference - } \\
\text { untreated) fibres }\end{array}$ & & \\
\hline $\begin{array}{l}\mathrm{C} 1 \text { - composite } \\
\text { material made of } \\
\text { PLA and SJL } \\
(\mathrm{NaOH} \text { treated }) \\
\text { fibres }\end{array}$ & & \\
\hline $\begin{array}{l}\text { C2 - composite } \\
\text { material made of } \\
\text { PLA and SJL } \\
\text { (MMT nanoclay } \\
\text { treated) fibres }\end{array}$ & & \\
\hline $\begin{array}{l}\text { C3 - composite } \\
\text { material made of } \\
\text { PLA and SJL } \\
\text { (MMT and citric } \\
\text { acid CA treated) } \\
\text { fibres }\end{array}$ & & \\
\hline
\end{tabular}

The results of pure PLA and its composites biodegradability are shown in Figure 2. A biodegradation experiment was conducted in the period of five days. According to the weight loss measurements it could be concluded that fibre reinforcements increased the degradation rate compared to neat PLA. Biodegradation rate of PLA composites depends on the biodegradability of all components and the nature of their miscibility [9]. It has been already concluded in our previous research that due to weak adsorption force between the clay particles and the fibre surface - Sample C2 show inappropriate interface properties, which influences faster degradation of such composite material. By comparing used enzyme concentrations, it is visible that the best results were obtained with $50 \%$ Savinase enzyme after 5 days of treatment. Recent study of Singh et al. [10] showed that the incorporation of MMT into PLA increased the biodegradation rate and the effect depends on the organic modifier used in the clays, thus degradation depends on the presence of excess - $\mathrm{OH}$ groups in the MMT and its dispersion through matrix which is also visible through experiment group 50\%E120h.

Katović et al. investigated properties of SJL fibres and their associated residues after various extraction methods - traditional sea water retting and microwave assisted alkali retting [15]. They have compared chemical composition content of SJL stem before and after fibre extraction and found out that chemical composition of residue after extraction depends on the chosen extraction method. Microwave assisted alkali treated residues have shown increase in cellulose and lignin content compared to sea water retted residues for approximately $5 \%$ and $14 \%$.

Considering such increase in lignin content and the fact that after SJL fibre extraction approx. $90 \%$ of residue remains unused, we came to the point for further investigation of possible usage of SJL residues as feedstock in bioenergy production.

In order to achieve solid biofuel standardization, ISO TC 238 is working on drafting and publishing of international solid biofuel standards, which set out the expected values of fuel properties for various types of biomass, i.e. proximate and ultimate analysis and determination of heating values [19].

The non-combustible and combustible properties of the SJL residues after fibre extraction by sea water retting and microwave assisted alkali retting are shown in Tables 2 and 3 . 


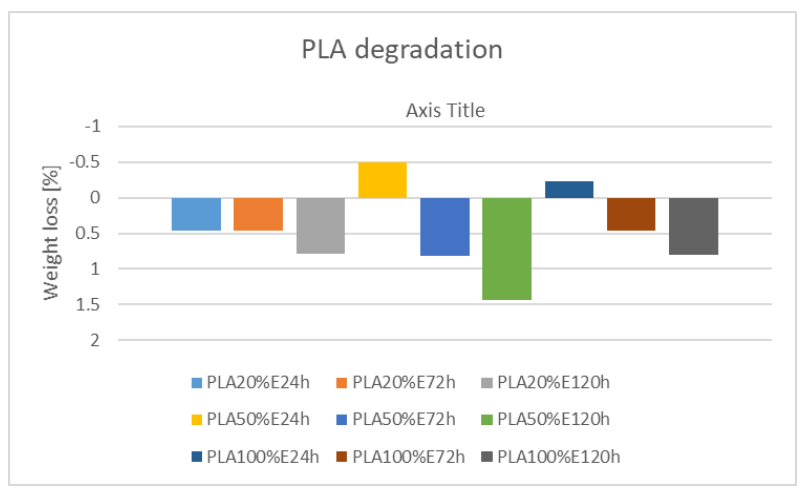

a)

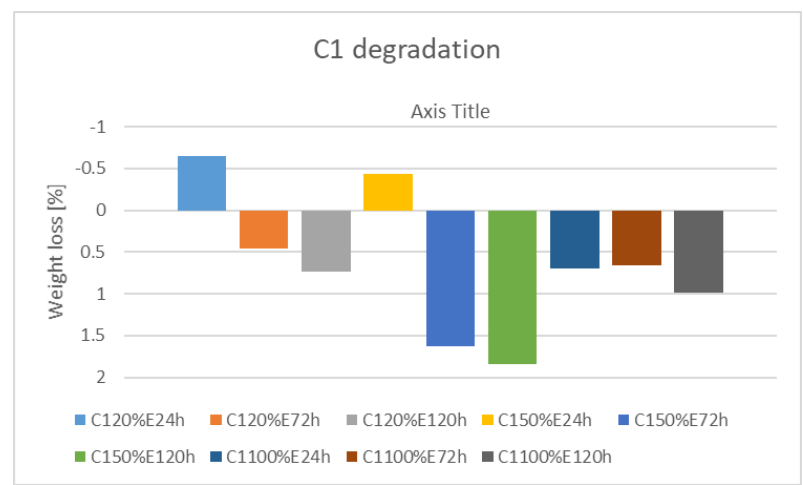

c)

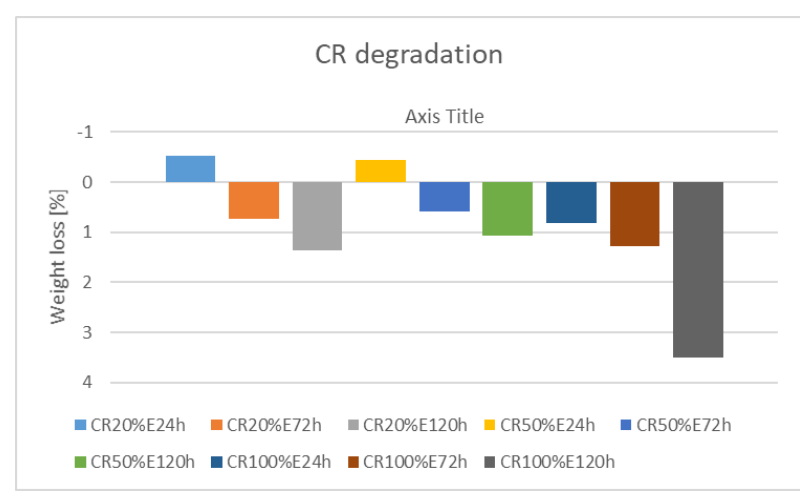

b)

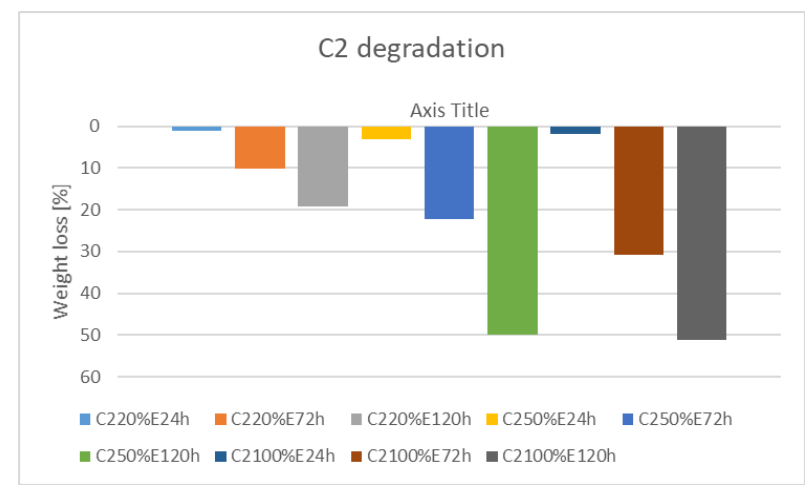

d)

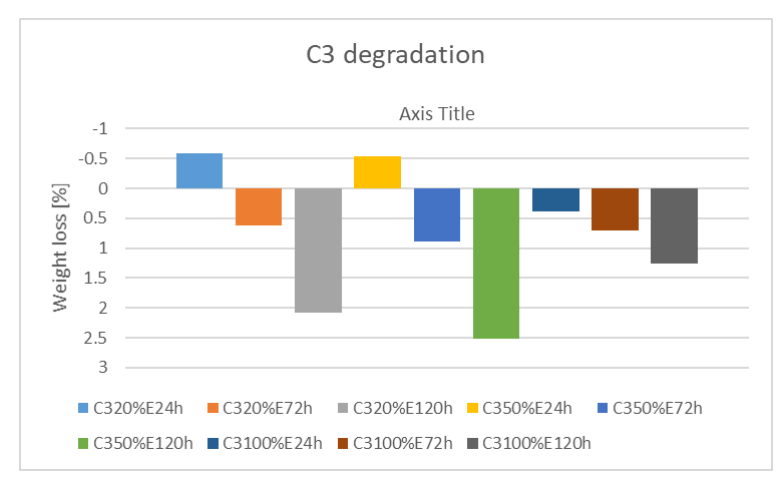

e)

Figure 2. Weight loss percentage of PLA and its composites after enzymatic degradation, symbol explanations in Table 1

Table 2. Non-combustible matter content in the SJL residues after fibre extraction

\begin{tabular}{|c|c|c|c|c|c|}
\hline & $\mathrm{MC}(\%, \mathrm{db})$ & $\mathrm{AC}(\%, \mathrm{db})$ & $\mathrm{FC}(\%, \mathrm{db})$ & Coke $(\%, \mathrm{db})$ & Nitrogen $(\%)$ \\
\hline 0 & $6.45 \mathrm{a} \pm 0.156$ & $2.38 \mathrm{a} \pm 0.095$ & $7.60 \mathrm{a} \pm 2.705$ & $9.98 \mathrm{a} \pm 2.698$ & $0.97 \mathrm{a} \pm 0.022$ \\
\hline Sea Water & $7.46 \mathrm{~b} \pm 0.133$ & $4.37 \mathrm{~b} \pm 0.301$ & $10.47 \mathrm{a} \pm 1.897$ & $14.84 \mathrm{a} \pm 1.819$ & $0.39 \mathrm{~b} \pm 0.012$ \\
\hline Microwave & $6.53 \mathrm{a} \pm 0.092$ & $4.77 \mathrm{~b} \pm 0.045$ & $13.22 \mathrm{a} \pm 2.701$ & $18.00 \mathrm{ba} \pm 2.668$ & $0.18 \mathrm{c} \pm 0.004$ \\
\hline Significance & $<0.05^{*}$ & $<0.05^{*}$ & $0.3160 \mathrm{NS}$ & $<0.05^{*}$ & $<0.05^{*}$ \\
\hline
\end{tabular}

where $\mathrm{db}$ - dry basis; MC - moisture content; AC - ash content; FC - fixed carbon; Different letters within a column indicate significant differences at the $5 \%$ level; significance ${ }^{*} \mathrm{p}<0.05$, NS - non significant. 
Table 3. Combustible matter content with higher and lower heating values in the SJL residues after fibre extraction

\begin{tabular}{|c|c|c|c|c|c|c|c|}
\hline & $\begin{array}{c}\text { Carbon } \\
(\%)\end{array}$ & $\begin{array}{c}\text { Sulphur } \\
(\%)\end{array}$ & $\begin{array}{c}\text { Hydrogen } \\
(\%)\end{array}$ & $\begin{array}{c}\text { Oxygen } \\
(\%)\end{array}$ & $\begin{array}{c}\text { VM } \\
(\%, \mathrm{db})\end{array}$ & $\begin{array}{c}\text { HHV } \\
(\mathrm{MJ} / \mathrm{kg})\end{array}$ & $\begin{array}{c}\text { LHV } \\
(\mathrm{MJ} / \mathrm{kg})\end{array}$ \\
\hline \multirow{2}{*}{0} & $46.51 \mathrm{a} \pm$ & $0.28 \mathrm{a} \pm$ & $7.12 \mathrm{a} \pm$ & $45.12 \mathrm{a} \pm$ & $83.50 \mathrm{~b} \pm$ & $18.83 \mathrm{a} \pm$ & $17.28 \mathrm{a} \pm$ \\
& 0.167 & 0.039 & 0.062 & 0.044 & 2.60 & 0.058 & 0.057 \\
\hline \multirow{2}{*}{ Sea Water } & $43.46 \mathrm{c} \pm$ & $0.29 \mathrm{a} \pm$ & $6.07 \mathrm{a} \pm$ & $49.80 \mathrm{a} \pm$ & $77.76 \mathrm{a} \pm$ & $17.23 \mathrm{a} \pm$ & $15.90 \mathrm{ba} \pm$ \\
& 0.127 & 0.010 & 0.918 & 0.793 & 1.85 & 0.122 & 0.121 \\
\hline \multirow{2}{*}{ Microwave } & $44.13 \mathrm{~b} \pm$ & $0.18 \mathrm{ab} \pm$ & $6.76 \mathrm{a} \pm$ & $48.75 \mathrm{ba} \pm$ & $75.52 \mathrm{a} \pm$ & $18.16 \mathrm{a} \pm$ & $16.69 \mathrm{a} \pm$ \\
& 0.039 & 0.007 & 0.000 & 0.050 & 2.64 & 1.112 & 1.112 \\
\hline Significance & $<0.05^{*}$ & $<0.05^{*}$ & $0.1467 \mathrm{NS}$ & $<0.05^{*}$ & $<0.05^{*}$ & $0.0907 \mathrm{NS}$ & $0.1293 \mathrm{NS}$ \\
\hline
\end{tabular}

where $\mathrm{db}$ - dry basis; VM - volatile matter; HHV - higher heating value; LHV - lower heating value; Different letters within a column indicate significant differences at the $5 \%$ level; significance $* \mathrm{p}<0.05, \mathrm{NS}-$ non significant.

All samples show significant difference in the non-combustible matter content, except fixed carbon values, where the content is not affected by different method of fibre extraction. The latter was proven by the ANOVA analysis. Fixed carbon represents covalently bonded carbon where higher content of bonded carbon correlates with the higher quality of biomass [20].

Moisture content is important for the purpose of the raw material storage [21]. Residues after microwave assisted extraction show no significant difference in moisture content compared to samples prior to fibre extraction. It is usually advised to keep the moisture content in biomass within the limits of $10-15$ $\%$ since higher moisture content can cause endothermic reaction [21, 22].

Ash is undesirable component of biomass, considering its catalytic influence on thermal decomposition. Higher ash amount points to higher carbon and gas concentrations. Melting point of biomass ash is low, so during thermal process melted ash produces slagging, which prevents energy transfer and lowers combustion efficiency [20]. The obtained ash content of residues after different fibre extractions show no significant difference. Its content is approx. $4.5 \%$, which is within the expected limits, since SJL belongs to herbaceous and agricultural biomass group that commonly reveals higher ash content than wood biomass, because of different chemical composition and higher mineral share, such as potassium, calcium, magnesium or phosphorus, which are ash-forming elements [23].

Coke content is considered as positive property of biomass and in Table 2 an increase in coke content for residues after microwave assisted extraction process can be observed.

The proximate analysis of two different biomass samples derived from different extraction methods show that volatile matter content is reduced while fixed carbon content increased, pointing to lower concentrations of light hydrocarbons like $\mathrm{CO}, \mathrm{CO}_{2}, \mathrm{H}_{2}$, moisture and tars in the samples which underwent microwave assisted extraction of fibres [2123].

Table 3 shows that by increasing carbon and hydrogen content, higher heating value also increases because $\mathrm{C}$ and $\mathrm{H}$ oxidised during combustion by exothermic reactions (formation of $\mathrm{CO}_{2}$ and $\mathrm{H}_{2} \mathrm{O}$ ) [24]. The highest heating values were obtained for residues after microwave assisted fibre extraction, with HHV of $18.16 \mathrm{MJ} / \mathrm{kg}$ and related LHV of 16.69 $\mathrm{MJ} / \mathrm{kg}$.

Although, SJL biomass from residues after fibre extraction show satisfying properties for solid biofuel production. It could be also pretreated by using biomass torrefaction technology through which physical or chemical characteristics of biomass are modified on purpose, before it is used for final 
conversion into a useful energy carrier. Such pre-treatment significantly reduces chlorine and other undesirable components of raw biomass making it more suitable for power generation in pulverised coal fired power plants [25].

\section{CONCLUSION}

In this paper, Spanish Broom products in the form of composite material reinforced with its fibres and in the form of residues left after fibre extraction were investigated.

Biodegradation of PLA/SJL composites has been successfully performed by using Savinase $16 \mathrm{~L}$ enzyme for 5 days. The best results regarding loss of weight were obtained by $50 \%$ of enzyme concentration which is in fact too high quantity to be used for enzymatic treatments. Therefore, further research will be carried out with several different enzymes suitable for the degradation of PLA and natural fibres. Although, biodegradable plastic won't solve all the problems related to plastic, hopefully it will reduce the environmental impact compared to fossil-based plastic.

Since the most important role of Spanish Broom crop is its utilization for the bast fibre production, a huge disadvantage is in organic residue left after the fibre extraction that represents almost $90 \mathrm{wt} \%$ of initial stem weight from which fibres were extracted. In present day we are witnessing the rise of biomass energy industry since the European Commission has set a long-term goal to develop a competitive, resource efficient and low carbon economy by 2050 .

Based on the obtained results of moisture, ash, fixed carbon, coke, volatile matter, nitrogen, sulphur, carbon, hydrogen and oxygen content, as well as the obtained heating values, it can be concluded that the residues after fibre extraction can be further utilized as raw material for solid biofuel production in order to achieve more efficient and sustainable production, leading to EU goals of circular economy and bioeconomy.

From the results obtained in this study, it can be concluded that Spanish Broom besides its application in biocomposites' production, is also a promising crop for various applications in biofuels industry.

\section{REFERENCES}

[1] S. Bischof, Z. Kovacevic, From Weed to Fabric, University of Zagreb Faculty of Textile Technology, Zagreb, 2013.

[2] World Programme for the Census of Agriculture 2020, Volume 1: Programme, Concepts and Definitions, FAO Statistical Development Series 15, Food and Agriculture Organization of the United Nations, Rome, 2017, http://www.fao.org/world-censusagriculture/en/, Accessed: June 21, 2019.

[3] Z. Kovačević, S. Bischof Vukušić, M. Zimniewska, Comparison of Spanish broom (Spartium Junceum L.) and flax (linum usitatissimum) fibre, Textile Research Journal 82(2012) 17, 17861798.

[4] S.R. Djafari Petroudy, Physical and Mechanical properties of Natural Fibres, In: Advanced High Strength Natural Fibre Composites in Construction, eds. M. Fan, F. Fu, Woodhead Publishing, UK, 2017.

[5] L.K. Kian, N. Saba, M. Jawaid, M.T.H. Sultan, A review on processing techniques of bast fibers nanocellulose and its polylactic acid (PLA) nanocomposites, International Journal of Biological Macromolecules, 121(2019), 1314-1328.

[6] P. Pecas, H. Carvalho, H. Salman, M. Leite, Natural Fibre Composites and Their Applications: A Review, Journal of Composites Science 2(2018) 66, 1-20.

[7] Z. Kovačević, S. Bischof, E. Vujasinović, The potential of nanoclay modified Spartium junceum L. fibres used as reinforcement in PLA matrix 
composites for automotive applications, International Journal of Nanotechnology 15(2018) 8/9/10, 695-700.

[8] S. Dixit, R. Goel, A. Dubey, P.R. Shivhare, T. Bhalavi, Natural Fibre Reinforced Polymer Composite Materials - A Review, Polymers from Renewable Resources 8(2017) 2, 71-78.

[9] T. Malwela, S.S. Ray, Enzymatic degradation behavior of nanoclay reinforced biodegradable PLA/PBSA blend composites, International Journal of Biological Macromolecules 77(2015), 131-142.

[10] N.K. Singh, B.P. Das Purkayastha, M. Panigrahi, R.K. Gautam, R.M. Banik, P. Maiti, Enzymatic Degradation of Polylactide/Layered Silicate Nanocomposites: Effect of Organic Modifiers, Journal of Applied Polymer Science 127(2013), 2465-2474.

[11] N.K. Kalita, M.K. Nagar, C. Mudenur, A. Kalamdhad, V. Katiyar, Biodegradation of modified Poly(lactic acid) based biocomposite films under thermophilic composting conditions, Polymer Testing (2019), doi: 10.1016/j.polymertesting.2019.02.021.

[12] N. Choksi, H. Desai, Synthesis of biodegradable polylactic acid polymer by using lactic acid monomer, International Journal of Applied Chemistry 13(2017) 2, 377-384.

[13] S.L. Cosentino, Climatic conditions, soil properties and physiology of fiber crops, Summer school "From Production to final Use" $21^{\text {st }}$ July 2013, Catania - Italy, http://www.fibrafp7.net, Accessed: June 15, 2019.

[14] N. Bilandzija, N. Voca, B. Jelcic, V. Jurisic, A. Matin, M. Grubor, T. Kricka, Evaluation of Croatian agricultural solid biomass energy potential, Renewable \& Sustainable Energy Reviews 93(2018), 225-230.

[15] D. Katović, A. Katović, A. Antonović, Extraction Methods of Spanish Broom (Spartium Junceum L.), Drvna Industrija 62(2011), 255-261.

[16] Z. Kovačević, M. Krncevic, A. Katovic, D. Katovic, Spanish broom - a forgotten textile raw material, Tekstil 59(2010), 410-421.

[17] Z. Kovacevic, S. Bischof, M. Fan, The influence of Spartium junceum L. fibres modified with montmorrilonite nanoclay on the thermal properties of PLA biocomposites, Composites Part B, Engineering 78(2015) 1, 122-130.

[18] Z. Kovacevic, S. Bischof, E. Vujasinovic, M. Fan, The influence of pre-treatment of Spartium junceum L. fibres on the structure and mechanical properties of PLA biocomposites, Arabian Journal of Chemistry 12(2019) 4, 449-463, doi: 10.1016/j.arabjc.2016.08.004.

[19] N. Bilandzija, N. Voca, T. Kricka, A. Matin, V. Jurisic, Energy potential of fruit tree pruned biomass in Croatia, Spanish Journal of Agricultural Research 10(2012) 2, 292-298.

[20] N. Bilandzija, V. Jurisic, N. Voca, J. Leto, A. Matin, S. Sito, T. Kricka, Combustion properties of Miscanthus $x$ giganteus biomass - Optimization of harvest time, Journal of the Energy Institute 90(2017), 528-533.

[21] T. Krička, A. Matin, N. Bilandžija, V. Jurišić, A. Antonović, N. Voća, M. Grubor, Biomass valorisation of Arundo donax L., Miscanthus $x$ giganteus and Sida hermaphrodita for biofuel production, International Agrophysics 31(2017), 575-581.

[22] I. Lopes Motta, N. Toscano Miranda, R. M. Filho, M.R. Wolf Maciel, Biomass gasification in fluidized beds: A review of biomass moisture content and operating pressure effects, Renewable and Sustainable Energy Reviews 94(2018), 998-1023.

[23] S. Vassilev, C. G. Vassileva, Y-C. Song, W-Y. Li, J. Feng, Ash contents and ashforming elements of biomass and their significance for solid biofuel combustion, Fuel 208(2017), 377-409.

[24] P. Roy, A. Dutta, J. Gallant, Hydrothermal Carbonization of Peat Moss and Herbaceous Biomass (Miscanthus): A potential route for 
bioenergy, Energies 11(2018) 2794, 114.

[25] J. Koppejan, M. Cremers, Biomass pretreatment for bioenergy, Policy report, IEA Bioenergy (2019), https://www.ieabioenergy.com/wpcontent/uploads/2019/04/Pretreatment_P olicyReport.pdf, Accessed: June 20, 2019.

\section{Acknowledgements}

This research was funded and supported by Croatian Science Foundation under the project 9967 ADVANCETEX: Advanced textile materials by targeted surface modification and the European commission via H2020 BBIDEMO project No. 745012 „GRowing is funded by.Advanced industrial Crops on marginal lands for biorEfineries - GRACE". 